OPEN ACCESS

Edited by:

Alberto A. Rasia-Filho, Federal University of Health Sciences,

Brazil

Reviewed by:

Deepak Prakash Srivastava,

King's College London, UK

Maya Frankfurt,

Hofstra North Shore LIJ School of

Medicine, USA

${ }^{*}$ Correspondence:

Ignacio Camacho-Arroyo

camachoarroyo@gmail.com

Specialty section: This article was submitted to

Systems Biology,

a section of the journal

Frontiers in Psychiatry

Received: 02 July 2015 Accepted: 02 November 2015 Published: 20 November 2015

Citation:

Hansberg-Pastor V, GonzálezArenas A, Piña-Medina AG and

Camacho-Arroyo I (2015) Sex Hormones Regulate Cytoskeletal Proteins Involved in Brain Plasticity.

Front. Psychiatry 6:165. doi: 10.3389/fpsyt.2015.00165

\section{Sex Hormones Regulate Cytoskeletal Proteins Involved in Brain Plasticity}

\author{
Valeria Hansberg-Pastor ${ }^{1}$, Aliesha González-Arenas ${ }^{2}$, Ana Gabriela Piña-Medina ${ }^{3}$ and \\ Ignacio Camacho-Arroyo ${ }^{*}$
}

'Departamento de Biología, Facultad de Química, Universidad Nacional Autónoma de México, Mexico City, Mexico, ${ }^{2}$ Departamento de Medicina Genómica y Toxicología Ambiental, Instituto de Investigaciones Biomédicas, Universidad Nacional Autónoma de México, Mexico City, Mexico, ${ }^{3}$ Unidad de Investigación en Reproducción Humana, Instituto Nacional de Perinatología-Facultad de Química, Universidad Nacional Autónoma de México, Mexico City, Mexico

In the brain of female mammals, including humans, a number of physiological and behavioral changes occur as a result of sex hormone exposure. Estradiol and progesterone regulate several brain functions, including learning and memory. Sex hormones contribute to shape the central nervous system by modulating the formation and turnover of the interconnections between neurons as well as controlling the function of glial cells. The dynamics of neuron and glial cells morphology depends on the cytoskeleton and its associated proteins. Cytoskeletal proteins are necessary to form neuronal dendrites and dendritic spines, as well as to regulate the diverse functions in astrocytes. The expression pattern of proteins, such as actin, microtubule-associated protein 2, Tau, and glial fibrillary acidic protein, changes in a tissue-specific manner in the brain, particularly when variations in sex hormone levels occur during the estrous or menstrual cycles or pregnancy. Here, we review the changes in structure and organization of neurons and glial cells that require the participation of cytoskeletal proteins whose expression and activity are regulated by estradiol and progesterone.

Keywords: sex hormones, estradiol, progesterone, brain, glial cells, plasticity

\section{INTRODUCTION}

Sex steroid hormones are known to play an important role during development and adulthood, regulating different functions and features of the central nervous system (CNS), such as brain differentiation, reproductive behavior, learning, and memory as well as neuroprotection. Structural plasticity is highly involved in the functional adaptation of the CNS in response to different environmental and physiological stimuli, including changes in hormone levels. In particular, female sex hormones can modify the size, morphology, synaptic density, and function of neuronal cells as well as the morphology of glial cells in sex steroid-responsive structures of the CNS (1). These changes are due to modifications in the neuronal and glial cytoskeleton where intracellular signals converge to regulate the direction and speed of outgrowth of different cell structures. Actin filaments, microtubules (MTs), and intermediate filaments, as well as the proteins associated with them, play a major role in synapse and dendritic spine formation (2). Neuronal projections are not only dependent on neuronal activity but also reliant on glial cells. The glia has an essential role in regulating the activity of CNS, where a mutual communication between glial cells and neurons exists. The activity and modifications in glial cell morphology also affect the formation and maintenance of synaptic contacts $(3,4)$. In this review, we will focus on the effects of female sex hormones on the 
expression and regulation of cytoskeletal proteins, contributing to the remodeling of the adult brain.

\section{SEX HORMONES AND THE BRAIN}

Female sex hormones are known to have a wide range of effects in the brain regulating not only reproductive processes but also cognitive functions. Estradiol (E2) and progesterone (P4) are cholesterol-derived hormones that, given their lipophilic structure, can easily cross the blood-brain barrier and interact with their specific receptors in different target cells of the brain. These hormones are also synthesized inside the brain. P4 and E2 levels have been detected in different brain areas such as hypothalamus and hippocampus with concentration differences between female and male animals (5-7), and their synthesis in neurons and glial cells have been demonstrated $(8,9)$. Moreover, pregnenolone, a cholesterol metabolite used by neurons for the biosynthesis of $\mathrm{P} 4$ and E2, is also produced by the glia $(10,11)$. This implies that the actions of sex hormones in neuronal plasticity are the result of adrenal, gonadal, and brain local synthesis.

E2 and P4 effects depend on the signaling pathway they activate, which can be either through intracellular receptors (classical mechanism) or membrane receptors (nonclassical mechanism) (12). Female sex hormone receptors are expressed in different brain areas, such as the hippocampus, hypothalamus, cortex, cerebellum, medial amygdala, substantia nigra, and ventral tegmental area (13-18). In the classical mechanism of action, sex hormones enter the cell and interact with their intracellular receptors, progesterone receptors $\mathrm{A}$ and $\mathrm{B}$ (PR-A and PR-B), and estrogen receptors $\alpha$ and $\beta$ (ER $\alpha$ and $\operatorname{ER} \beta)$. In the cell, the receptors are associated with chaperones like the heat shock proteins 70 and 90 (Hsp70/90). The ligand-receptor interaction induces conformational changes in the latter that promotes the receptor phosphorylation, dissociation of the Hsp70/90 complex, and dimerization. The active receptor binds to specific DNA sequences named hormone response elements (HREs) located within the regulatory regions of target genes. The receptor also recruits coactivators and chromatin remodeling complexes that enhance the attachment of the basal transcription machinery to induce gene expression. Genes that lack HRE can be hormonally induced through the interaction of the receptor with transcription factors like Sp1 and Ap1 (19-22). Once the receptor dissociates from the DNA, it is marked for degradation through the $26 \mathrm{~S}$ proteasome $(23,24)$.

Hormone receptor activation can also induce diverse signaling pathways like those mediated by MAPKs, PI3K/Akt, and PKC (25-27), regulate second messenger cascades (28) or modulate the actions of neurotransmitter receptors (29). These mechanisms are regulated through PR and ER located in the cytoplasm, nucleus, or plasma membrane (30-32) or through other membrane receptors that have different biochemical and pharmacological properties $(33,34)$. These signaling pathways may eventually induce gene transcription. The different mechanisms of action of sex hormones may account for the diverse signaling profiles observed in various brain regions.

The effects of E2 and P4 in the brain depend on hormonal levels and receptor expression. The levels of P4 and E2 fluctuate throughout the life span of the rat modifying different parts of the CNS and causing diverse alterations in brain anatomy, physiology, and behavior $(35,36)$. E2- and P4-induced plasticity occurs when neuronal cells dynamically respond to hormonal stimuli by modifying its connectivity network and biochemical composition. Brain plasticity can be long lasting, and even the same stimuli can induce different plastic responses at different ages (37). The most dramatic change induced by sex hormones in brain is the driving of its sexual differentiation. During the fetal-neonatal period, sex hormones permanently modify the brain architecture $(13,38)$. Neurogenesis, cell differentiation, synaptogenesis, axon guidance, myelination, cell migration, and cell death are some of the main mechanisms occurring during sexual differentiation of the brain. These mechanisms alter the brain area, volume, cell number, cytoarchitecture, cell activity, synaptic connectivity, and neurochemical content $(1,39)$.

After brain differentiation, sex hormone levels in the brain are transitory and fluctuating, and induce the continuous functional adaptation of the CNS throughout the life span of the animal, particularly in females $(35,40)$. The main periods where sex hormone levels fluctuate during the life span are the beginning of puberty, reproductive cycles, pregnancy, and menopause. During these phases, alterations in the number of neurons and synapses, glial complexity, morphological variations in dendrites and synapses, and changes in neurotransmitter levels have been reported (41-44). These changes promote neuronal and glial remodeling that is critical for cognition, learning, and memory. For example, spatial working memory varies during rat pregnancy, and the memory retention enhanced by E2 is maintained by P4 $(45,46)$. Further data show that E2 and P4 modify neuronal morphology of the hippocampus of rats and monkeys, an important region for memory consolidation $(47,48)$. It has been recently reported that P4 enhances object recognition memory consolidation through mTOR and Wnt signaling (49). There is also evidence that both E2 and P4 can modulate GABAergic, dopaminergic, glutamatergic, and serotoninergic neurotransmission, as well as the release of a variety of growth factors from the astroglia (50-52). Sex hormones also modify the outgrowth of astrocytic processes and the amount of neuronal membranes they can cover, facilitating neuronal synaptic connectivity and plasticity $(3,51$, 53). Morphological changes induced by E2 and P4 in the brain as well as the cytoskeletal proteins participating in brain plasticity, which are modulated by sex hormones, are reviewed in detail in the next sections.

\section{SEX HORMONES MODIFY THE NUMBER, SIZE, AND BIOCHEMICAL CHARACTERISTICS OF DENDRITIC SPINES}

The effects of $\mathrm{E} 2$ and $\mathrm{P} 4$ on neuronal plasticity are related to adaptive changes in the structure and function of neurons that may contribute to learning, memory, and recovery after diverse insults (1). Reorganizational effects of sex hormones on neuronal circuitry involve different morphological events, including changes in dendritic length $(54,55)$ and neuronal membrane organization 
related to synaptic and dendritic spine formation (56). Dendritic spines, first described by Ramón y Cajal in 1888 (57, 58), are small protrusions of the dendritic membrane of neurons that are specialized in synaptic transmission. They consist of an actin-rich head attached to the neuron by a thin neck and contain the necessary postsynaptic machinery to receive the input of an excitatory synapse. Dendritic spines and synapses can be stable or change dynamically, even in very short time lapses, in their morphology and biochemical composition upon different stimuli $(59,60)$. Sex hormones have been shown to alter the structure and function of these neuronal structures through both rapid and long-term mechanisms $(32,61)$.

Recent studies show that E2 can modify synaptic plasticity and dendritic spine formation in hippocampal neurons through rapid signaling cascades, such as MAPKs, PI3K/Akt, and PKC $(43,62)$, which can also involve the activation of ER $\alpha$ (63-65). Signaling pathways such as ERK1/2 and Akt have been reported to be essential for E2-mediated spinogenesis in primary cortical neurons, and the activation of $\operatorname{ER} \beta$ can mimic the rapid E2-induced spinogenesis and synaptogenesis. These results suggest that in cortical neurons, E2 via ER $\beta$ promotes neuronal cell remodeling by increasing the number of excitatory synapses (66). The same study showed that $30 \mathrm{~min}$ of E2 treatment induces the recruitment of postsynaptic density protein 95 (PSD-95) to the newly formed dendritic spines, while in the nascent, synapses promotes the recruitment of the $N$-methyl-D-aspartate (NMDA) receptor subunit GluN1 (66). These proteins are essential for the formation of new synaptic contacts, suggesting that E2 promotes the recruitment of the required proteins to allow pre and postsynapses to form connections. Other studies show that E2 promotes the phosphorylation of NMDA receptors through the activation of the src tyrosine kinase/MAPK pathway, and thus enhances long-term potentiation (LTP) of synapse transmission (67). Also, cyclic changes in E2 levels during the estrous cycle of rats are associated with changes in the state of NR2 subunit tyrosine phosphorylation of NMDA receptors in the hippocampus and alter LTP (68). In addition to E2, rapid effects of P4 have been reported in primary cultures of cortical neurons, where P4 increases the density and number of dendritic spines through changes in cell cytoskeleton components (69). The rapid effects of $\mathrm{P} 4$ on dendritic spines have been proposed to occur through the activation of GABA receptors and through the recently described PR membrane component $1(65,70)$.

Non-rapid effects of sex hormones in the brain have also been observed, and reports show that they induce the formation of excitatory synapses both in vitro and in vivo $(47,48)$, thus modulating $\operatorname{LTP}(71,72)$. For example, ovariectomized rats treated with E2 for $48 \mathrm{~h}$ showed an enhanced density of apical dendritic spines in the CA1 region of the hippocampus that was related to an increase in the number of functional synapses (73). Interestingly, the density of dendritic spines in the hippocampal pyramidal cells changes during the estrous cycle of the rat; more spines are observed during the afternoon of the proestrus and the morning of the diestrus when E2 and P4 levels are high $(5,74)$. Moreover, Kato and colleagues demonstrated that the concentration of E2 in the hippocampus correlates with the serum concentration observed during the estrous cycle (5). However, hormone levels in the brain vary between newborn female and male animals (7, $75)$, suggesting the importance of considering the developmental stage and sex of the animal for a better evaluation of the observed hormone effects. Other studies show that adult male rats have more spines than female animals in the medial nucleus of the amygdala, and that the density of these spines varies throughout the estrous cycle of virgin rats, showing fewer spines during the proestrus and estrus phases when compared to diestrus $(76,77)$. Remarkably, the inhibition of E2 synthesis in females but not in males results in LTP and synapse loss in hippocampal slices (78, 79), which points toward an important effect of local E2 synthesis on synaptic plasticity.

E2 also induces the formation of neural pathways during fetal and neonatal life that modulate the activity of synapses in adulthood (80). The role of P4 in synaptic plasticity is less studied, but it has been reported that in cerebellar slices of neonatal rats, $\mathrm{P} 4$ promotes dendritic outgrowth and synaptogenesis in Purkinje neurons contributing to the formation of new neuronal connections in this structure (81). Immature cerebellar Purkinje cells treated with $\mathrm{P} 4$ for $24 \mathrm{~h}$ increased the dendritic length and spine density but this effect was not observed in mature cells. The effect was blocked when cells were treated with PR antagonist RU486, which suggest a classical mechanism of action for this hormone in the cerebellum (70). Interestingly, chronic treatment with P4 (60 days) decreases hippocampal synaptic transmission and LTP in hippocampal slices from ovariectomized adult rats (65). These data suggest that in mature cells, P4 effects on dendritic spine formation and LTP are less clear than for E2. With respect to the importance of the glia, primary cultures of rat astrocytes treated with $\mathrm{P} 4$ for $24 \mathrm{~h}$ express higher levels of agrin, a protein shown to be important for synapse formation. The P4-induced increase in agrin in astrocytes enhances synapse formation in hippocampal neurons (82). These data show the strong relation between glia and neurons that can be modulated by sex hormones. Many of these changes observed in the adult brain eventually converge on the cell cytoskeleton. Neuronal and glial cytoskeletal reorganization depends on its own dynamic nature and on the expression, regulation, and activity of the proteins associated with it.

\section{THE CYTOSKELETON IN NEURONAL PLASTICITY}

The neuronal cytoskeleton is divided into three specific structural complexes with different properties: neurofilaments (NFs) or intermediate filaments, MTs, and microfilaments (MFs), each one with a specific composition and organization, and even a particular cell type or subcellular localization. NFs are heteropolymers composed of heavy, medium, and light NFs protein chains. NFs are very abundant in neuronal axons and have extremely elastic fibrous properties that help to maintain the asymmetrical shape of the neuronal cell and to regulate the axon diameter and growth (83). In addition to NFs, MTs are mainly located in the neuronal axon, where microtubule-associated proteins (MAPs) like Tau help to stabilize them. MTs are composed of heterodimers of $\alpha$ and $\beta$ tubulin that give them an intrinsic polarity important for their dynamic nature (84). MTs and their MAPs (MAP1B, MAP2, 
etc.) participate in the promotion of neurite extension, the induction of distinctive morphologies between axons and dendrites, axonal transport, neuronal plasticity, and neuronal degeneration (85). Lastly, MFs are constituted by actin filaments, and their polymerization dynamic is closely associated with the activity of actin-binding proteins (ABPs) like drebrin and ADF/cofilin. MFs are involved in a broad range of aspects that are crucial for the establishment and the correct function of synapses, axonal cones growth, shape, size, remodeling of dendritic spines, and protein trafficking (86).

The neuronal cell shape, the dendritic spines, and synapse morphology, as well as the speed of synapse growth, can be hormonally modulated (87-89). Morphological changes depend on the cell cytoskeleton, and its dynamic regulation helps to shape these diverse neuronal structures. Experimental evidence suggests that MFs and MTs play a prominent role in the establishment and stability balance in neuronal structures, such as synapses and dendritic spines, which are constantly constructed and modified throughout life $(90,91)$. Dendrites and their spines have important implications in neuronal activity. Cytoskeleton studies show that MFs are highly accumulated in the dendrite spines where a pool of dynamic MFs is located at the tip of the spine, while a pool of stable drebrin-actin filaments is located in the spine core. These stable drebrin-actin filaments interact with dynamic MTs whose presence is enhanced by synaptic activity. The interplay between MFs and MTs is therefore important for the temporal and local regulation of spine morphology $(2,92,93)$. These cytoskeleton rearrangements are controlled by members of the Rho family of GTPases (e.g., RhoA, Rac1), which regulate the activity of different cytoskeleton-associated proteins such as MAPs and ABPs $(94,95)$.

Synaptic connections are very important for neuronal communication, so they are highly regulated. Astrocytes are active players in neuronal transmission and plasticity. They can extend their projections to surround neuronal somata, dendrites, and synapses. Actually, the majority of synapses are ensheathed by astrocytes providing the support for the organization and well functioning of the synaptic connections (Figure 1) (96). Astrocytic processes have in their structure bundles of intermediate filaments constituted by glial fibrillary acidic protein (GFAP). These projections gradually form a network that infiltrates the brain tissue in order to effectively associate with neuronal synapses $(97,98)$.

Different cytoskeletal proteins are modified when morphological plastic changes occur in the brain in response to diverse stimuli. Gonadal sex hormones are known to affect diverse morphological processes as mentioned in the text, so we will further review the effects of $\mathrm{E} 2$ and $\mathrm{P} 4$ on three of the main cytoskeletal proteins present in CNS cells.

\section{E2 AND P4 PROMOTE THE REMODELING OF THE ACTIN CYTOSKELETON}

Actin is a highly conserved protein involved in many important cellular processes, including contraction, cytokinesis, transport of vesicles and organelles, cell signaling processes, establishment and maintenance of cell junctions and cell shape, cell movement, and synaptic plasticity $(99,100)$. These actin features are mainly attributed to filamentous actin, which represents the major cytoskeletal component of dendritic spines (101). Hence, the morphological changes in spine shape, size, and number are determined by local actin dynamics (102). The overall process of cytoskeleton remodeling, including the formation of new MFs and their interaction with the plasma membrane, depends on the participation of diverse ABPs.

P4 and E2 are key modulators of cell morphology and movement in diverse cellular types, including neurons (103-106). Most of the events leading to cytoskeletal rearrangement are rapidly performed by changes in the phosphorylation state of ABPs. A key protein that controls actin remodeling is the WASP-family verprolin homologous protein 1 (WAVE1) whose activation by phosphorylation is essential to regulate actin polymerization through the actin-related protein Arp2/3 complex $(107,108)$. In this regard, E2 and $\mathrm{P} 4$ administration to rat cortical neurons leads to WAVE1 phosphorylation on 310, 397, and 441 serine residues. Phospho-WAVE1 is then redistributed toward the cell membrane at the sites of dendritic spine formation. An ER $\alpha$ rapid extranuclear signaling activates GTPase Rac1, which recruits the cyclin-dependent kinase 5 triggering WAVE1 phosphorylation. E2 also induces actin remodeling via the activation of $A B P$ moesin through the RhoA and ROCK2 pathway (109). Moesin phosphorylation on Thr558 is essential to link the actin cytoskeleton to a variety of membrane-anchoring proteins, such as CD43 and CD44 (110, 111). Rat cortical neurons treated with E2 and P4 exhibit an increase in phosphorylation of moesin, which impacts the formation of neuronal spines $(69,109)$. Actin polymerization in dendritic spines of rat hippocampal slices has been linked to E2 activation of RhoA pathway that leads to the inhibition of the filament-severing protein cofilin (112). Interestingly, treatment of hippocampal slices with aromatase inhibitor letrozole promotes actin filaments depolymerization as a result of cofilin activation, thus leading to synapse loss (113). Also, it has been reported a transient spine density increase in cortical neurons treated with E2 dependent on a Rap/AF-6/ERK1/2 pathway (114). Another study reported that E2 induced an increase in the length of dendrites in the central nucleus of the amygdala and in the hypothalamic ventromedial nucleus that was due to the inactivation of cofilin and variations in the composition of GluA1 and GluA2 subunits of the AMPA receptors (87). The changes in the actin cytoskeleton suggest a possible relation between dendrite and dendritic spine remodeling and changes in animal behavior regulated by $\mathrm{E} 2$.

There is evidence that demonstrates that P4 increases the outspread of the neuronal growth cones of dorsal ganglia neurons, an effect related to morphological changes in the components of the actin cytoskeleton. The enhanced cytoskeletal dynamic within the growth cone after P4 treatment occurred through a classical mechanism of action because the effect was blocked by the administration of PR antagonist RU486 (115). These data show that E2 and P4 induce morphological changes in shape, size, and number of neuronal spines, and that these changes are determined by actin dynamics, suggesting a continuous plastic transformation (Figure 1). 


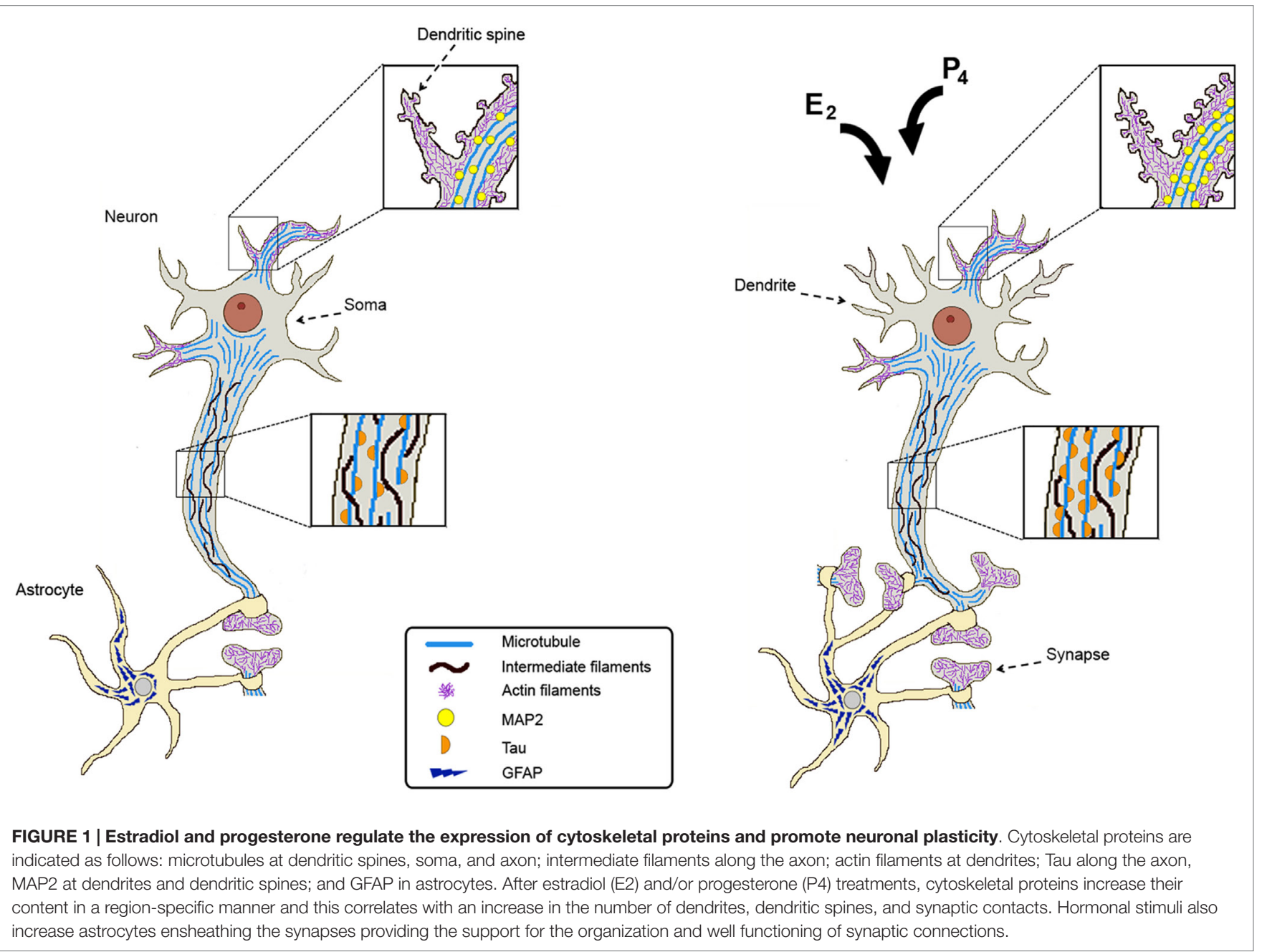

\section{E2 AND P4 EFFECTS ON MICROTUBULE-ASSOCIATED PROTEIN 2 AND TAU EXPRESSION}

Microtubule-associated proteins regulate MTs dynamics by selectively binding to distinct conformations of polymerized and unpolymerized tubulin. Among them, the structural MAPs stabilize the MTs by binding along the length of the MT (116). In the brain, the main structural MAPs are MAP1, MAP2, and Tau, each one presenting several isoforms. Neuronal MAPs are differentially expressed during brain development: MAP1B is expressed in early stages of newly forming axons, MAP1A is expressed in mature axons, and both MAP2 and Tau isoforms are expressed during development and adulthood, predominantly in dendrites and axons, respectively $(117,118)$. In particular, Tau isoforms are of clinical relevance, given that they are the major component of paired helical filaments found in Alzheimer's disease (AD) and other brain diseases $(85,119)$.

It has been reported that MAP2 is preferentially located at the shaft of dendrites, where it may have the capacity to regulate morphological plasticity at a slow rate when compared to the rapid morphological changes regulated by actin filaments in dendritic spines (91). In the CA1 region of the hippocampus of MAP2-deficient mice, apical dendrites were shorter than those of wild-type animals $(120,121)$, suggesting an important role for MAP2 in dendrite elongation.

The expression pattern of MAPs and their correlation with ultrastructural changes induced by ovarian steroids have been observed in different brain areas and under specific hormonal and developmental conditions $(89,122-124)$. In medial basal hypothalamic neurons maintained for 4 days in vitro (DIV), E2 increased the levels of the $58-\mathrm{kDa}$ Tau isoform but it did not change that of tubulin; by 7 DIV, E2 also increased the content of MAP1 and MAP2 (125). In cultured hypothalamic dissociated neurons, E2 exerted differential effects on neurite outgrowth depending on gender: the induction and differentiation of axons occur later in time, and cells develop fewer and shorter primary neurites in female fetuses compared with neurons taken from male fetuses. A comparable increase in Tau and MAP2 expression was observed in neuronal cultures obtained from both female and male rats (126). Another study showed that in dissociated cell cultures form embryonic rat medial amygdala, E2 induces 
the differentiation of axons after 21 DIV and increases the total dendritic length of the cultured neurons. These changes were correlated with the respective increase in Tau and MAP2 expression but not with that of $\alpha$-tubulin (127).

In the hippocampus of ovariectomized rats, an increase in MAP2 protein content has been reported after the treatment with E2, P4, or both hormones for 24 and $48 \mathrm{~h}$, with no changes in the frontal cortex. Interestingly, these hormones did not modify MAP2 mRNA content in the hippocampus. These data suggest that MAP2 is involved in the structural changes induced by $\mathrm{E} 2$ and $\mathrm{P} 4$ in hippocampus and that its expression is regulated at a postranscriptional level (123). Interestingly, it has been demonstrated that the chronic administration of ovarian hormones immediately after ovariectomy modifies the content of MAP2 and Tau in the hippocampus and prefrontal cortex of the rat. Short- (2 weeks) and long-term (18 weeks) treatments with E2 or P4 had different and even opposing effects on MAP2 and Tau expression. None of the proteins changed its content in the prefrontal cortex in response to E2, but remarkably, P4 decreased MAP2 after short-term treatment and increased both MAP2 and Tau in this brain region after a long-term treatment. In the hippocampus, short- and long-term treatments with E2 increased MAP2 content, while P4 did it only after a short-term treatment (128). These data suggest that P4 regulates MAP2 expression depending on the brain region and the exposure time to the hormone, and it would be interesting to study P4 effects in E2-primed animals. Other authors have found similar tissue-specific effects with $\mathrm{P} 4$. For instance, in ovariectomized rats, an acute injection of $\mathrm{P} 4$ had no effect on Tau expression in the hypothalamus after $24 \mathrm{~h}$, while it induced a decrease in the cerebellum (129). Another study reported that after P4 treatment for 3 days, the loss of MAP2 induced by acute spinal cord injury was attenuated, suggesting that P4 is partially responsible for preserving neuronal ultrastructure at the peripheral level (130). These studies highlight the importance of the type and length of treatment, the doses of E2 and P4 used and as well as the brain region studied; a summary of these results are shown in Table 1.

During pregnancy, circulating sex hormones are increased in the rat; E2 levels are two-fold and P4 three-fold higher compared with the hormone levels during proestrus day $(131,132)$. The brain displays diverse morphophysiological changes during pregnancy including cell plasticity $(36,45,133)$. Furthermore, in the medial preoptic area (POA), late pregnant rats have bigger neuronal somata than ovariectomized rats (134), suggesting that E2 and P4 play an important role in neuronal morphology. Changes in the expression of MAP2 and Tau in the hippocampus and POA were evaluated during rat gestation and the beginning of lactation. In the hippocampus of pregnant rats, the content of MAP2 decreased during pregnancy, contrary to ovariectomized rats treated with $\mathrm{P} 4$ during 2 weeks $(128,132)$. These differences in $\mathrm{P} 4$ effects suggest a very fine regulation of MAP2 protein expression that depends on the characteristics of the hormonal stimulus. In addition, no significant changes in MAP2 content were detected in POA through rat pregnancy, suggesting that tissue-specific factors are involved in the regulation of MAP2 expression (132), which could be related to the different roles that have specific brain areas in the behavioral patterns observed throughout pregnancy.

Differences in Tau protein content and in its phosphorylation pattern in different brain regions may be related to Tau key role in the dynamic remodeling of neuronal cytoskeleton observed during gestation. Tau content and its phosphorylation are modified in a tissue-specific manner in the pregnant rat (132). In the hypothalamus, the hippocampus, and the cerebellum, Tau content diminished on gestation day 14 compared to gestation day 2 , and only in the cerebellum and the hippocampus, this decrease was sustained until day 18 of pregnancy. Phosphorylated Tau at Ser396 (PhosphoTau) progressively augmented in the hippocampus, the hypothalamus, and the cerebellum throughout pregnancy, whereas in POA, the content of PhosphoTau decreased on day 21 of gestation (135). Tau phosphorylation at Ser396 results in tubulin depolymerization and MTs destabilization (136). Recent data show that Tau has an important role in synaptic plasticity in the hippocampus and that Ser396 phosphorylation is required for long-term depression (LTD), which is associated with the weakening of synaptic connections (137). LTD is important for certain cognitive processes like novelty discrimination and behavioral flexibility (138), which are fundamental for the pregnant rat.

Changes in MAP2 and Tau expression have been seen even after days of E2 or P4 treatment (1 day and 18 weeks), suggesting a classical mechanism of action where intracellular PR and ER are involved. However, not only MAP2 and Tau are under sex hormones influence, there are other proteins involved in synaptogenesis (neuroligins) or in spine density formation (PSD-95), whose expression also depends on P4 and E2 levels. Neuroligin-2 expression in the uterus is upregulated after 3 days of treatment with E2, P4, or E2 + P4 (139). Six-hour of E2 treatment stimulates the phosphorylation of Akt, as well as the phosphorylation of the translation initiation factor $4 \mathrm{E}$ binding protein 1 . In turn, the activation of these signaling intermediates promotes the increase in the translation of PSD-95 in cultured neuronal cells (140). These data demonstrate that E2 and P4 induce the expression of different proteins involved in neuronal plasticity by different mechanisms of action.

\section{SEX HORMONES AND THEIR IMPACT ON GLIAL FIBRILLARY ACIDIC PROTEIN EXPRESSION}

Nowadays, it is evident that astrocytes respond to various stimuli by increasing their intracellular calcium levels, releasing gliotransmitters (141) or rapidly extending their projections (97). The large astrocytic processes have bundles of intermediate filaments that have GFAP as one of their principal constituent. GFAP has been implicated in cell motility (142), astrocyte proliferation (143), directional mobility of vesicles (144), the integrity of the blood-brain barrier, myelination (145), neuroprotection, and brain plasticity $(146,147)$.

Glial fibrillary acidic protein expression can be modified by factors such as neuronal damage, stress, age, or hormones (148). Sex hormones can regulate the astrocyte number during rat 
TABLE 1 | Changes in MAP2A and Tau protein content in the hippocampus and frontal cortex of ovariectomized rats after acute and chronic E2 and P4 treatments.

\begin{tabular}{|c|c|c|c|c|c|c|c|}
\hline \multirow[t]{2}{*}{ Brain area } & \multirow[t]{2}{*}{ Time of treatment } & \multicolumn{2}{|c|}{ E2 } & \multirow[t]{2}{*}{ Time of treatment } & \multicolumn{2}{|c|}{ P4 } & \multirow[t]{2}{*}{ Reference } \\
\hline & & MAP2A & Tau & & MAP2A & Tau & \\
\hline Hippocampus & $48 \mathrm{~h}$ & Increase & Increase & $24 \mathrm{~h}$ & Increase & Increase & Reyna-Neyra et al. (123) \\
\hline Frontal cortex & & NC & NC & & NC & NC & \\
\hline Hippocampus & 2 weeks & Increase & $\mathrm{NC}$ & 2 weeks & Increase & NC & Camacho-Arroyo et al. (128) \\
\hline Frontal cortex & & NC & NC & & Decrease & NC & \\
\hline Hippocampus & 18 weeks & Increase & $\mathrm{NC}$ & 18 weeks & $\mathrm{NC}$ & $\mathrm{NC}$ & Camacho-Arroyo et al. (128) \\
\hline Frontal cortex & & NC & NC & & Increase & Increase & \\
\hline
\end{tabular}

The study of two brain regions and the modifications in protein content after acute (24 and 48 h) and chronic (2 and 18 weeks) hormone treatments.

NC, no change in protein content.

hippocampal development (149), enhance the extension of GFAP immunoreactive processes in astrocytes from hippocampal slices in vitro (150), and modulate astrocyte reaction after brain injury (151, 152). Interestingly, GFAP fluctuates during the estrous cycle of the rat and has a marked sex difference, at least in the hippocampus. The CA1, CA3, and dentate gyrus regions of the hippocampus had an increase in GFAP immunoreactivity during proestrus (high levels of P4 and E2) compared to male animals and diestrus females. During proestrus, astrocyte morphology changed to rounded cell bodies with numerous and short processes, whereas cells with stellate shape with few and long processes were present in the hippocampus of males and diestrus females (153).

During pregnancy and the beginning of lactation, a differential expression pattern of GFAP was found in the brain. GómoraArrati and coworkers analyzed GFAP expression on days 2, 14, 18 , and 21 of gestation and the second day of lactation (L2) of the rat because of the marked changes in E2 and P4 levels observed in these days. It was found that in the hippocampus, GFAP content showed a constant increase of $25 \%$ throughout pregnancy and L2, while in the cerebellum, it first decreased more than $30 \%$ during pregnancy and later increased on L2 (41\%). Interestingly, GFAP content increased in the frontal cortex and hypothalamus on gestational days 14 and 18, respectively. Then, a subsequent decrease was observed in the following days of pregnancy that persisted until L2 in the hypothalamus, in the cortex increased (42\%) in L2. Contrary, a dramatic decrease in GFAP content was observed in POA on day 14 followed by an increase that was maintained throughout the rest of the studied days. These data suggest a differential expression of GFAP that should be associated with changes in brain function during these reproductive stages (154). Other reports showed that the chronic administration of $\mathrm{P} 4$ in ovariectomized rats resulted in a reduction of GFAP content in the hippocampus (128). This result contrasts with that observed under physiological conditions, highlighting the importance of hormonal concentration and exposure time on the content of GFAP in the brain.

E2 also modulates astrocytic form and function in the hypothalamus of rodents during development and adulthood. In the developing arcuate nucleus, E2 increased stellation of astrocytes through increases in neuronal GABA synthesis (155). Likewise, E2 positively regulates the length of GFAP-positive processes through ER $\alpha$ activation in astrocytes of ovariectomized animals
(156). Still, there is no evidence whether E2-induced changes in astrocytes morphology are indirect effects of the E2 stimulation of neighboring neurons. Other reports show that in ovariectomized rats with entorhinal cortex lesions, E2 replacement inhibits the increase in GFAP (mRNA and protein level) and enhances neurite outgrowth. It is proposed that the decrease in GFAP alters the organization of laminin and this increases the fibrillary extracellular matrix supporting axonal growth (157). In adult castrated male rats, GFAP expression increased in the hippocampus, however, high levels of E2 prevented this castration-induced increase in GFAP (148). Interestingly, as evidence described herein shows that most of the effects of steroid hormones on GFAP expression are long term, and the data suggest that both P4 and E2 dynamically modify both the content and the distribution of GFAP.

\section{SEX HORMONES IN NEUROGENESIS, NEUROPROTECTION AND DISEASE}

E2 and P4 have been shown to exert both neuroprotective and neuroregenerative roles in several models of brain damage (158-161). Neurogenesis in the adult animal occurs in the cells lining the subventricular zone and the dentate gyrus of the hippocampus, where cells can remain quiescent or be activated to finally produce neuronal progenitor cells that later migrate into diverse brain regions $(37,162)$. It has been observed that neurogenesis in the dentate gyrus is higher in female animals than in males, probably because of the variations in gonadal hormones (163). Also, chronic treatment (21 days) of ovariectomized rats with E2 + P4 increased neurogenesis in the dentate gyrus (164). Regarding brain damage, E2 can induce neurogenesis post stroke in the adult animal (165) that could be through the activation of ERs $(166,167)$, and P4 has been reported to increase neurological functions after a traumatic brain injury (168). As a prerequisite for neuronal transmission, the new neurons need to have a well-defined axon and dendrites, which is known as neuronal polarization. The cytoskeleton is fundamental for the process of neuronal polarization (169) and as described in this review, sex hormones can modulate the expression and regulation of important proteins of the cytoskeleton.

The neuroprotective effects of sex hormones have been observed under different brain insults and diseases. In an 
ischemic model, $\mathrm{P} 4$ reduces neurite growth inhibitory proteins like RhoA and Nogo-A, and E2 diminishes the loss of neurons and synapses from de CA1 hippocampal region (170, 171). In neurodegenerative diseases like $\mathrm{AD}, \mathrm{E} 2$ administration reduces the expression of $\beta$-amyloid precursor protein, which is cleaved into amyloid beta $(\mathrm{A} \beta)$ and accumulated in plaques in the brain $(172,173) . A \beta$ is involved in the generation of $A D$ and it has been reported that estrogens can reduce its concentrations in the brain (174). Also, the formation of tangles of Tau protein caused by its abnormal phosphorylation, another $\mathrm{AD}$ characteristic, has been shown to be counteracted by E2 $(175,176)$. In fact, some studies have demonstrated that E2 therapy reduces the risk of presenting this neurodegenerative disease in women as well as diminishes the cognitive impairment associated with it (177, 178). Neuroprotective properties of E2 and P4 have also been observed in vitro in neuronal models of cell death induced by glutamate in hippocampal and cortical neurons $(179,180)$. Both E2 and P4 can induce recovery from neurodegeneration by increasing the synthesis of myelin components in both Schwann cells and oligodendrocytes $(10,181,182)$. In fact, $\mathrm{P} 4$ promotes the expression of the myelin basic protein in cultured rat oligodendrocytes $(183,184)$. Taken together, sex hormones promote the recovery of brain tissue upon an insult and also protect against neurodegenerative diseases.

\section{REFERENCES}

1. Parducz A, Hajszan T, Maclusky NJ, Hoyk Z, Csakvari E, Kurunczi A, et al. Synaptic remodeling induced by gonadal hormones: neuronal plasticity as a mediator of neuroendocrine and behavioral responses to steroids. Neuroscience (2006) 138:977-85. doi:10.1016/j.neuroscience.2005.07.008

2. Gordon-Weeks PR, Fournier AE. Neuronal cytoskeleton in synaptic plasticity and regeneration. J Neurochem (2014) 129:206-12. doi:10.1111/jnc.12502

3. Chowen JA, Azcoitia I, Cardona-Gomez GP, Garcia-Segura LM. Sex steroids and the brain: lessons from animal studies. J Pediatr Endocrinol Metab (2000) 13:1045-66. doi:10.1515/JPEM.2000.13.8.1045

4. Garcia-Segura LM, Lorenz B, DonCarlos LL. The role of glia in the hypothalamus: implications for gonadal steroid feedback and reproductive neuroendocrine output. Reproduction (2008) 135:419-29. doi:10.1530/REP-07-0540

5. Kato A, Hojo Y, Higo S, Komatsuzaki Y, Murakami G, Yoshino H, et al. Female hippocampal estrogens have a significant correlation with cyclic fluctuation of hippocampal spines. Front Neural Circuits (2013) 7:149. doi:10.3389/ fncir.2013.00149

6. Rhoda J, Corbier P, Roffi J. Gonadal steroid concentrations in serum and hypothalamus of the rat at birth: aromatization of testosterone to $17 \beta$-estradiol. Endocrinology (1984) 114:1754-60. doi:10.1210/endo-114-5-1754

7. Konkle ATM, McCarthy MM. Developmental time course of estradiol, testosterone, and dihydrotestosterone levels in discrete regions of male and female rat brain. Endocrinology (2011) 152:223-35. doi:10.1210/en.2010-0607

8. Mellon SH, Vaudry H. Biosynthesis of neurosteroids and regulation of their synthesis. Int Rev Neurobiol (2001) 46:33-78. doi:10.1016/ S0074-7742(01)46058-2

9. Mellon SH, Griffin LD, Compagnone NA. Biosynthesis and action of neurosteroids. Brain Res Brain Res Rev (2001) 37:3-12. doi:10.1016/ S0165-0173(01)00109-6

10. Koenig HL, Schumacher M, Ferzaz B, Thi AN, Ressouches A, Guennoun R, et al. Progesterone synthesis and myelin formation by Schwann cells. Science (1995) 268:1500-3. doi:10.1126/science.7770777

11. Hojo Y, Hattori T-A, Enami T, Furukawa A, Suzuki K, Ishii H-T, et al. Adult male rat hippocampus synthesizes estradiol from pregnenolone by cytochromes P45017alpha and P450 aromatase localized in neurons. Proc Natl Acad Sci U S A (2004) 101:865-70. doi:10.1073/pnas.2630225100

\section{CONCLUSION}

E2 and P4 play a key role in different neuronal and glial cell functions that involve changes in synaptic plasticity, and therefore in cell structure (Figure 1). These sex steroids induce changes in the brain cells cytoskeleton in addition to the content and activity of cytoskeletal proteins, such as MAP2, TAU, and GFAP. However, these changes significantly vary depending on sex, age, cerebral region, as well as the dose and length of exposure to these hormones.

\section{PERSPECTIVES}

There are several promising research areas that will give us a better understanding of the participation of sex steroid hormone action in cytoskeletal proteins regulation. The knowledge of the action mechanisms used by sex hormones to modulate cytoskeleton and therefore synaptic plasticity will be important to understand how learning and memory skills change during puberty, reproductive cycle, pregnancy, lactation, and menopause.

\section{ACKNOWLEDGMENTS}

This work was supported by the project PAPIIT IN201414, DGAPA, UNAM, Mexico.

12. Ellmann S, Sticht H, Thiel F, Beckmann MW, Strick R, Strissel PL. Estrogen and progesterone receptors: from molecular structures to clinical targets. Cell Mol Life Sci (2009) 66:2405-26. doi:10.1007/s00018-009-0017-3

13. Sakuma Y. Gonadal steroid action and brain sex differentiation in the rat. J Neuroendocrinol (2009) 21:410-4. doi:10.1111/j.1365-2826.2009.01856.x

14. Carrillo-Martínez GE, Gómora-Arrati P, González-Arenas A, RoldánRoldán G, González-Flores O, Camacho-Arroyo I. Effects of RU486 in the expression of progesterone receptor isoforms in the hypothalamus and the preoptic area of the rat during postpartum estrus. Neurosci Lett (2011) 504:127-30. doi:10.1016/j.neulet.2011.09.016

15. Guennoun R, Labombarda F, Gonzalez Deniselle MC, Liere P, De Nicola AF, Schumacher M. Progesterone and allopregnanolone in the central nervous system: response to injury and implication for neuroprotection. J Steroid Biochem Mol Biol (2015) 146C:48-61. doi:10.1016/j.jsbmb.2014.09.001

16. Waters EM, Thompson LI, Patel P, Gonzales AD, Ye HZ, Filardo EJ, et al. G-protein-coupled estrogen receptor 1 is anatomically positioned to modulate synaptic plasticity in the mouse hippocampus. J Neurosci (2015) 35:2384-97. doi:10.1523/JNEUROSCI.1298-14.2015

17. Guerra-Araiza C, Villamar-Cruz O, Gonzalez-Arenas A, Chavira R, CamachoArroyo I. Changes in progesterone receptor isoforms content in the rat brain during the oestrous cycle and after oestradiol and progesterone treatments. J Neuroendocrinol (2003) 15:984-90. doi:10.1046/j.1365-2826.2003.01088.x

18. Guerra-Araiza C, Cerbon MA, Morimoto S, Camacho-Arroyo I. Progesterone receptor isoforms expression pattern in the rat brain during the estrous cycle. Life Sci (2000) 66:1743-52. doi:10.1016/S0024-3205(00)00497-5

19. Helsen C, Claessens F. Looking at nuclear receptors from a new angle. $\mathrm{Mol}$ Cell Endocrinol (2013) 382:97-106. doi:10.1016/j.mce.2013.09.009

20. Schülke J-P, Wochnik GM, Lang-Rollin I, Gassen NC, Knapp RT, Berning $B$, et al. Differential impact of tetratricopeptide repeat proteins on the steroid hormone receptors. PLoS One (2010) 5:e11717. doi:10.1371/journal. pone. 0011717

21. Cato L, Neeb A, Brown M, Cato ACB. Control of steroid receptor dynamics and function by genomic actions of the cochaperones p23 and Bag-1L. Nucl Recept Signal (2014) 12:e005. doi:10.1621/nrs.12005

22. Abdel-Hafiz HA, Horwitz KB. Post-translational modifications of the progesterone receptors. J Steroid Biochem Mol Biol (2014) 140:80-9. doi:10.1016/j. jsbmb.2013.12.008 
23. Lange CA, Shen T, Horwitz KB. Phosphorylation of human progesterone receptors at serine- 294 by mitogen-activated protein kinase signals their degradation by the 26 S proteasome. Proc Natl Acad Sci U S A (2000) 97:1032-7. doi:10.1073/pnas.97.3.1032

24. Villamar-Cruz O, Manjarrez-Marmolejo J, Alvarado R, Camacho-Arroyo I. Regulation of the content of progesterone and estrogen receptors, and their cofactors SRC- 1 and SMRT by the $26 \mathrm{~S}$ proteasome in the rat brain during the estrous cycle. Brain Res Bull (2006) 69:276-81. doi:10.1016/j. brainresbull.2005.12.006

25. Deng H, Yin L, Zhang X-T, Liu L-J, Wang M-L, Wang Z-Y. ER- $\alpha$ variant ER- $\alpha 36$ mediates antiestrogen resistance in ER-positive breast cancer stem/progenitor cells. J Steroid Biochem Mol Biol (2014) 144(Pt B):417-26. doi:10.1016/j.jsbmb.2014.08.017

26. Garrido P, Salehzadeh F, Duque-Guimaraes DE, Al-Khalili L. Negative regulation of glucose metabolism in human myotubes by supraphysiological doses of 17 $\beta$-estradiol or testosterone. Metabolism (2014) 63:1178-87. doi:10.1016/j.metabol.2014.06.003

27. González-Arenas A, Peña-Ortiz MA, Hansberg-Pastor V, Marquina-Sánchez B, Baranda-Ávila N, Nava-Castro K, et al. PKC $\alpha$ and PKC $\delta$ activation regulates transcriptional activity and degradation of progesterone receptor in human astrocytoma cells. Endocrinology (2015) 156:1010-22. doi:10.1210/ en.2014-1137

28. Lishko PV, Botchkina IL, Kirichok Y. Progesterone activates the principal Ca2+ channel of human sperm. Nature (2011) 471:387-91. doi:10.1038/ nature 09767

29. Labombarda F, Ghoumari AM, Liere P, De Nicola AF, Schumacher M, Guennoun R. Neuroprotection by steroids after neurotrauma in organotypic spinal cord cultures: a key role for progesterone receptors and steroidal modulators of GABA(A) receptors. Neuropharmacology (2013) 71:46-55. doi:10.1016/j.neuropharm.2013.03.010

30. Micevych P, Christensen A. Membrane-initiated estradiol actions mediate structural plasticity and reproduction. Front Neuroendocrinol (2012) 33:331-41. doi:10.1016/j.yfrne.2012.07.003

31. Mueck AO, Ruan X, Seeger H, Fehm T, Neubauer H. Genomic and non-genomic actions of progestogens in the breast. J Steroid Biochem Mol Biol (2014) 142:62-7. doi:10.1016/j.jsbmb.2013.08.011

32. Levin ER. Extranuclear steroid receptors are essential for steroid hormone actions. Annu Rev Med (2015) 66:271-80. doi:10.1146/ annurev-med-050913-021703

33. Chaudhri RA, Schwartz N, Elbaradie K, Schwartz Z, Boyan BD. Role of ER $\alpha 36$ in membrane-associated signaling by estrogen. Steroids (2014) 81:74-80. doi:10.1016/j.steroids.2013.10.020

34. Prossnitz ER, Hathaway HJ. What have we learned about GPER function in physiology and disease from knockout mice? J Steroid Biochem Mol Biol (2015) 153:114-26. doi:10.1016/j.jsbmb.2015.06.014

35. Nugent BM, Tobet SA, Lara HE, Lucion AB, Wilson ME, Recabarren SE, et al. Hormonal programming across the lifespan. Horm Metab Res (2012) 44:577-86. doi:10.1055/s-0032-1312593

36. Hillerer KM, Jacobs VR, Fischer T, Aigner L. The maternal brain: an organ with peripartal plasticity. Neural Plast (2014) 2014:574159. doi:10.1155/2014/574159

37. Kolb B, Gibb R. Brain plasticity and behaviour in the developing brain. J Can Acad Child Adolesc Psychiatry (2011) 20:265-76.

38. Maekawa F, Tsukahara S, Kawashima T, Nohara K, Ohki-Hamazaki H. The mechanisms underlying sexual differentiation of behavior and physiology in mammals and birds: relative contributions of sex steroids and sex chromosomes. Front Neurosci (2014) 8:242. doi:10.3389/fnins.2014.00242

39. Chung WCJ, Auger AP. Gender differences in neurodevelopment and epigenetics. Pflugers Arch (2013) 465:573-84. doi:10.1007/s00424-013-1258-4

40. Juraska JM, Sisk CL, DonCarlos LL. Sexual differentiation of the adolescent rodent brain: hormonal influences and developmental mechanisms. Horm Behav (2013) 64:203-10. doi:10.1016/j.yhbeh.2013.05.010

41. Farinetti A, Tomasi S, Foglio B, Ferraris A, Ponti G, Gotti S, et al. Testosterone and estradiol differentially affect cell proliferation in the subventricular zone of young adult gonadectomized male and female rats. Neuroscience (2015) 286:162-70. doi:10.1016/j.neuroscience.2014.11.050

42. Patel R, Moore S, Crawford DK, Hannsun G, Sasidhar MV, Tan K, et al. Attenuation of corpus callosum axon myelination and remyelination in the absence of circulating sex hormones. Brain Pathol (2013) 23:462-75. doi:10.1111/bpa.12029

43. Hasegawa Y, Hojo Y, Kojima H, Ikeda M, Hotta K, Sato R, et al. Estradiol rapidly modulates synaptic plasticity of hippocampal neurons: involvement of kinase networks. Brain Res (2015) 1621:147-61. doi:10.1016/j. brainres.2014.12.056

44. Schumacher M, Hussain R, Gago N, Oudinet J-P, Mattern C, Ghoumari AM. Progesterone synthesis in the nervous system: implications for myelination and myelin repair. Front Neurosci (2012) 6:10. doi:10.3389/ fnins.2012.00010

45. Galea LA, Ormerod BK, Sampath S, Kostaras X, Wilkie DM, Phelps MT. Spatial working memory and hippocampal size across pregnancy in rats. Horm Behav (2000) 37:86-95. doi:10.1006/hbeh.1999.1560

46. Sandstrom NJ, Williams CL. Memory retention is modulated by acute estradiol and progesterone replacement. Behav Neurosci (2001) 115:384-93. doi:10.1037/0735-7044.115.2.384

47. Gould E, Woolley CS, Frankfurt M, McEwen BS. Gonadal steroids regulate dendritic spine density in hippocampal pyramidal cells in adulthood. $J$ Neurosci (1990) 10:1286-91.

48. Woolley CS, McEwen BS. Estradiol regulates hippocampal dendritic spine density via an N-methyl-D-aspartate receptor-dependent mechanism. $J$ Neurosci (1994) 14:7680-7.

49. Fortress AM, Frick KM. Hippocampal Wnt signaling: memory regulation and hormone interactions. Neuroscientist (2015). doi:10.1177/1073858415574728

50. Garcia-Segura LM, Melcangi RC. Steroids and glial cell function. Glia (2006) 54:485-98. doi:10.1002/glia.20404

51. Barth C, Villringer A, Sacher J. Sex hormones affect neurotransmitters and shape the adult female brain during hormonal transition periods. Front Neurosci (2015) 9:37. doi:10.3389/fnins.2015.00037

52. González-Flores O, Gómora-Arrati P, García-Juárez M, MirandaMartínez A, Armengual-Villegas A, Camacho-Arroyo I, et al. Progesterone receptor isoforms differentially regulate the expression of tryptophan and tyrosine hydroxylase and glutamic acid decarboxylase in the rat hypothalamus. Neurochem Int (2011) 59:671-6. doi:10.1016/j. neuint.2011.06.013

53. Sanchez AM, Flamini MI, Polak K, Palla G, Spina S, Mannella P, et al. Actin cytoskeleton remodelling by sex steroids in neurones. J Neuroendocrinol (2012) 24:195-201. doi:10.1111/j.1365-2826.2011.02258.x

54. Meisel RL, Luttrell VR. Estradiol increases the dendritic length of ventromedial hypothalamic neurons in female Syrian hamsters. Brain Res Bull (1990) 25:165-8. doi:10.1016/0361-9230(90)90269-6

55. Wong AM, Rozovsky I, Arimoto JM, Du Y, Wei M, Morgan TE, et al. Progesterone influence on neurite outgrowth involves microglia. Endocrinology (2009) 150:324-32. doi:10.1210/en.2008-0988

56. Garcia-Segura LM, Chowen JA, Parducz A, Naftolin F. Gonadal hormones as promoter of structural synaptic plasticity: cellular mechanisms. Prog Neurobiol (1994) 44:279-307. doi:10.1016/0301-0082(94)90042-6

57. García-López P, García-Marín V, Freire M. Three-dimensional reconstruction and quantitative study of a pyramidal cell of a Cajal histological preparation. $J$ Neurosci (2006) 26:11249-52. doi:10.1523/JNEUROSCI.3543-06.2006

58. Ramón y Cajal S. Sur la structure de lécorce cérébrale de quelques mammifères. La Cellule (1891) 7:125-76.

59. Nimchinsky EA, Sabatini BL, Svoboda K. Structure and function of dendritic spines. Annu Rev Physiol (2002) 64:313-53. doi:10.1146/annurev. physiol.64.081501.160008

60. Grienberger C, Chen X, Konnerth A. Dendritic function in vivo. Trends Neurosci (2015) 38:45-54. doi:10.1016/j.tins.2014.11.002

61. Hara Y, Waters EM, McEwen BS, Morrison JH. Estrogen effects on cognitive and synaptic health over the lifecourse. Physiol Rev (2015) 95:785-807. doi:10.1152/physrev.00036.2014

62. Hojo Y, Munetomo A, Mukai H, Ikeda M, Sato R, Hatanaka Y, et al. Estradiol rapidly modulates spinogenesis in hippocampal dentate gyrus: involvement of kinase networks. Horm Behav (2015) 74:149-56. doi:10.1016/j. yhbeh.2015.06.008

63. Murakami G, Hojo Y, Ogiue-Ikeda M, Mukai H, Chambon P, Nakajima K, et al. Estrogen receptor KO mice study on rapid modulation of spines and long-term depression in the hippocampus. Brain Res (2015) 1621:133-46. doi:10.1016/j.brainres.2014.12.002 
64. Sellers K, Raval P, Srivastava DP. Molecular signature of rapid estrogen regulation of synaptic connectivity and cognition. Front Neuroendocrinol (2015) 36:72-89. doi:10.1016/j.yfrne.2014.08.001

65. Baudry M, Bi X, Aguirre C. Progesterone-estrogen interactions in synaptic plasticity and neuroprotection. Neuroscience (2013) 239:280-94. doi:10.1016/j.neuroscience.2012.10.051

66. Sellers KJ, Erli F, Raval P, Watson IA, Chen D, Srivastava DP. Rapid modulation of synaptogenesis and spinogenesis by $17 \beta$-estradiol in primary cortical neurons. Front Cell Neurosci (2015) 9:137. doi:10.3389/fncel.2015.00137

67. Bi R, Broutman G, Foy MR, Thompson RF, Baudry M. The tyrosine kinase and mitogen-activated protein kinase pathways mediate multiple effects of estrogen in hippocampus. Proc Natl Acad Sci U S A (2000) 97:3602-7. doi: $10.1073 /$ pnas. 060034497

68. Bi R, Foy MR, Vouimba RM, Thompson RF, Baudry M. Cyclic changes in estradiol regulate synaptic plasticity through the MAP kinase pathway. Proc Natl Acad Sci U S A (2001) 98:13391-5. doi:10.1073/pnas.241507698

69. Sanchez AM, Flamini MI, Genazzani AR, Simoncini T. Effects of progesterone and medroxyprogesterone on actin remodeling and neuronal spine formation. Mol Endocrinol (2013) 27:693-702. doi:10.1210/me.2012-1278

70. Wessel L, Balakrishnan-Renuka A, Henkel C, Meyer HE, Meller K, BrandSaberi B, et al. Long-term incubation with mifepristone (MLTI) increases the spine density in developing Purkinje cells: new insights into progesterone receptor mechanisms. Cell Mol Life Sci (2014) 71:1723-40. doi:10.1007/ s00018-013-1448-4

71. Durand GM, Konnerth A. Long-term potentiation as a mechanism of functional synapse induction in the developing hippocampus. J Physiol Paris (1996) 90:313-5. doi:10.1016/S0928-4257(97)87905-3

72. Warren SG, Humphreys AG, Juraska JM, Greenough WT. LTP varies across the estrous cycle: enhanced synaptic plasticity in proestrus rats. Brain Res (1995) 703:26-30. doi:10.1016/0006-8993(95)01059-9

73. Yankova M, Hart SA, Woolley CS. Estrogen increases synaptic connectivity between single presynaptic inputs and multiple postsynaptic CA1 pyramidal cells: a serial electron-microscopic study. Proc Natl Acad Sci U S A (2001) 98:3525-30. doi:10.1073/pnas.051624598

74. Woolley CS, Gould E, Frankfurt M, McEwen BS. Naturally occurring fluctuation in dendritic spine density on adult hippocampal pyramidal neurons. $J$ Neurosci (1990) 10:4035-9.

75. Amateau SK, Alt JJ, Stamps CL, McCarthy MM. Brain estradiol content in newborn rats: sex differences, regional heterogeneity, and possible de novo synthesis by the female telencephalon. Endocrinology (2004) 145:2906-17. doi:10.1210/en.2003-1363

76. Rasia-Filho AA, Dalpian F, Menezes IC, Brusco J, Moreira JE, Cohen RS. Dendritic spines of the medial amygdala: plasticity, density, shape, and subcellular modulation by sex steroids. Histol Histopathol (2012) 27:985-1011.

77. Rasia-Filho AA, Fabian C, Rigoti KM, Achaval M. Influence of sex, estrous cycle and motherhood on dendritic spine density in the rat medial amygdala revealed by the Golgi method. Neuroscience (2004) 126:839-47. doi:10.1016/j. neuroscience.2004.04.009

78. Fester L, Rune GM. Sexual neurosteroids and synaptic plasticity in the hippocampus. Brain Res (2015) 1621:162-9. doi:10.1016/j.brainres.2014.10.033

79. Kretz O, Fester L, Wehrenberg U, Zhou L, Brauckmann S, Zhao S, et al. Hippocampal synapses depend on hippocampal estrogen synthesis. $J$ Neurosci (2004) 24:5913-21. doi:10.1523/JNEUROSCI.5186-03.2004

80. Maggi A, Perez J. Role of female gonadal hormones in the CNS: clinical and experimental aspects. Life Sci (1985) 37:893-906. doi:10.1016/0024-3205(85)90525-9

81. Sakamoto H, Ukena K, Tsutsui K. Dendritic spine formation in response to progesterone synthesized de novo in the developing Purkinje cell in rats. Neurosci Lett (2002) 322:111-5. doi:10.1016/S0304-3940(02)00077-0

82. Tournell CE, Bergstrom RA, Ferreira A. Progesterone-induced agrin expression in astrocytes modulates glia-neuron interactions leading to synapse formation. Neuroscience (2006) 141:1327-38. doi:10.1016/j. neuroscience.2006.05.004

83. Yuan A, Rao MV, Veeranna, Nixon RA. Neurofilaments at a glance. J Cell Sci (2012) 125:3257-63. doi:10.1242/jcs.104729

84. Sakakibara A, Ando R, Sapir T, Tanaka T. Microtubule dynamics in neuronal morphogenesis. Open Biol (2013) 3:130061. doi:10.1098/rsob.130061

85. Sergeant N, Buée L. Tau pathology. In: Nixon RA, Yuan A, editors. Cytoskeleton of the Nervous System. New York, NY: Springer (2011). p. 83-132.
86. Revenu C, Athman R, Robine S, Louvard D. The co-workers of actin filaments: from cell structures to signals. Nat Rev Mol Cell Biol (2004) 5:635-46. doi:10.1038/nrm1437

87. Ferri SL, Hildebrand PF, Way SE, Flanagan-Cato LM. Estradiol regulates markers of synaptic plasticity in the hypothalamic ventromedial nucleus and amygdala of female rats. Horm Behav (2014) 66:409-20. doi:10.1016/j. yhbeh.2014.06.016

88. Arevalo M-A, Santos-Galindo M, Bellini M-J, Azcoitia I, Garcia-Segura LM. Actions of estrogens on glial cells: implications for neuroprotection. Biochim Biophys Acta (2010) 1800:1106-12. doi:10.1016/j.bbagen.2009.10.002

89. Camacho-Arroyo I, Reyna-Neyra A, Mercado-Gómez O, Arias C. The role of estradiol and progesterone in the regulation of cytoskeletal proteins in the central nervous system. In: Pandala SG, editor. Recent Research Developments in Life Sciences. vol. 2, Kerala: Research Signpost (2004). p. 143-61.

90. Pollard TD, Borisy GG. Cellular motility driven by assembly and disassembly of actin filaments. Cell (2003) 112:453-65. doi:10.1016/ S0092-8674(03)00120-X

91. Kaech S, Parmar H, Roelandse M, Bornmann C, Matus A.Cytoskeletal microdifferentiation: a mechanism for organizing morphological plasticity in dendrites. Proc Natl Acad Sci U S A (2001) 98:7086-92. doi:10.1073/pnas.111146798

92. Sekino Y, Kojima N, Shirao T. Role of actin cytoskeleton in dendritic spine morphogenesis. Neurochem Int (2007) 51:92-104. doi:10.1016/j. neuint.2007.04.029

93. Shirao T, González-Billault C. Actin filaments and microtubules in dendritic spines. J Neurochem (2013) 126:155-64. doi:10.1111/jnc.12313

94. Jan Y-N, Jan LY. Branching out: mechanisms of dendritic arborization. Nat Rev Neurosci (2010) 11:316-28. doi:10.1038/nrn2836

95. Gonzalez-Billault C, Muñoz-Llancao P, Henriquez DR, Wojnacki J, Conde C, Caceres A. The role of small GTPases in neuronal morphogenesis and polarity. Cytoskeleton (Hoboken) (2012) 69:464-85. doi:10.1002/cm.21034

96. De Pittà M, Brunel N, Volterra A. Astrocytes: orchestrating synaptic plasticity? Neuroscience (2015). doi:10.1016/j.neuroscience.2015.04.001

97. Bernardinelli Y, Muller D, Nikonenko I. Astrocyte-synapse structural plasticity. Neural Plast (2014) 2014:232105. doi:10.1155/2014/232105

98. Middeldorp J, Hol EM. GFAP in health and disease. Prog Neurobiol (2011) 93:421-43. doi:10.1016/j.pneurobio.2011.01.005

99. Doherty GJ, McMahon HT. Mediation, modulation, and consequences of membrane-cytoskeleton interactions. Annu Rev Biophys (2008) 37:65-95. doi:10.1146/annurev.biophys.37.032807.125912

100. Dominguez R, Holmes KC. Actin structure and function. Annu Rev Biophys (2011) 40:169-86. doi:10.1146/annurev-biophys-042910-155359

101. Cohen RS, Chung SK, Pfaff DW. Immunocytochemical localization of actin in dendritic spines of the cerebral cortex using colloidal gold as a probe. Cell Mol Neurobiol (1985) 5:271-84. doi:10.1007/BF00711012

102. Fischer M, Kaech S, Wagner U, Brinkhaus H, Matus A. Glutamate receptors regulate actin-based plasticity in dendritic spines. Nat Neurosci (2000) 3:887-94. doi:10.1038/78791

103. Simoncini T, Scorticati C, Mannella P, Fadiel A, Giretti MS, Fu XD, et al. Estrogen receptor alpha interacts with Galpha13 to drive actin remodeling and endothelial cell migration via the RhoA/Rho kinase/moesin pathway. Mol Endocrinol (2006) 20:1756-71. doi:10.1210/me.2005-0259

104. Fu XD, Giretti MS, Baldacci C, Garibaldi S, Flamini M, Sanchez AM, et al. Extra-nuclear signaling of progesterone receptor to breast cancer cell movement and invasion through the actin cytoskeleton. PLoS One (2008) 3:e2790. doi:10.1371/journal.pone.0002790

105. Flamini MI, Sanchez AM, Goglia L, Tosi V, Genazzani AR, Simoncini T. Differential actions of estrogen and SERMs in regulation of the actin cytoskeleton of endometrial cells. Mol Hum Reprod (2009) 15:675-85. doi:10.1093/molehr/gap045

106. Giretti MS, Fu XD, De Rosa G, Sarotto I, Baldacci C, Garibaldi S, et al. Extra-nuclear signalling of estrogen receptor to breast cancer cytoskeletal remodelling, migration and invasion. PLoS One (2008) 3:e2238. doi:10.1371/ journal.pone. 0002238

107. Suetsugu S, Hattori M, Miki H, Tezuka T, Yamamoto T, Mikoshiba K, et al. Sustained activation of N-WASP through phosphorylation is essential for neurite extension. Dev Cell (2002) 3:645-58.

108. Kim Y, Sung JY, Ceglia I, Lee KW, Ahn JH, Halford JM, et al. Phosphorylation of WAVE1 regulates actin polymerization and dendritic spine morphology. Nature (2006) 442:814-17. 
109. Sánchez AM, Flamini MI, Fu XD, Mannella P, Giretti MS, Goglia L, et al. Rapid signaling of estrogen to WAVE1 and moesin controls neuronal spine formation via the actin cytoskeleton. Mol Endocrinol (2009) 23:1193-202. doi:10.1210/me.2008-0408

110. Tsukita S, Yonemura S. Cortical actin organization: lessons from ERM (ezrin/ radixin/moesin) proteins. J Biol Chem (1999) 274:34507-10. doi:10.1074/ jbc.274.49.34507

111. Louvet-Vallee S. ERM proteins: from cellular architecture to cell signaling. Biol Cell (2000) 92:305-16. doi:10.1016/S0248-4900(00)01078-9

112. Babayan AH, Kramár EA. Rapid effects of oestrogen on synaptic plasticity: interactions with actin and its signalling proteins. J Neuroendocrinol (2013) 25:1163-72. doi:10.1111/jne. 12108

113. Vierk R, Brandt N, Rune GM. Hippocampal estradiol synthesis and its significance for hippocampal synaptic stability in male and female animals. Neuroscience (2014) 274:24-32. doi:10.1016/j.neuroscience.2014.05.003

114. Srivastava DP, Woolfrey KM, Woolfrey K, Jones KA, Shum CY, Lash LL, et al. Rapid enhancement of two-step wiring plasticity by estrogen and NMDA receptor activity. Proc Natl Acad Sci U S A (2008) 105:14650-5. doi:10.1073/ pnas. 0801581105

115. Olbrich L, Wessel L, Balakrishnan-Renuka A, Boing M, Brand-Saberi B, Theiss C. Rapid impact of progesterone on the neuronal growth cone. Endocrinology (2013) 154:3784-95. doi:10.1210/en.2013-1175

116. Brouhard GJ, Rice LM. The contribution of $\alpha \beta$-tubulin curvature to microtubule dynamics. J Cell Biol (2014) 207:323-34. doi:10.1083/jcb.201407095

117. Halpain S, Dehmelt L. The MAP1 family of microtubule-associated proteins. Genome Biol (2006) 7:224. doi:10.1186/gb-2006-7-6-224

118. Sergeant N, Buée L. Cytoskeleton of the nervous system. Neurobiology (2011) 3:83-132. doi:10.1007/978-1-4419-6787-9

119. Hanger DP, Anderton BH, Noble W. Tau phosphorylation: the therapeutic challenge for neurodegenerative disease. Trends Mol Med (2009) 15:112-9. doi:10.1016/j.molmed.2009.01.003

120. Harada A, Teng J, Takei Y, Oguchi K, Hirokawa N. MAP2 is required for dendrite elongation, PKA anchoring in dendrites, and proper PKA signal transduction. J Cell Biol (2002) 158:541-9. doi:10.1083/jcb.200110134

121. Dehmelt L, Halpain S. The MAP2/Tau family of microtubule-associated proteins. Genome Biol (2005) 6:204. doi:10.1186/gb-2004-6-1-204

122. Murakami K, Fellous A, Baulieu EE, Robel P. Pregnenolone binds to microtubule-associated protein 2 and stimulates microtubule assembly. Proc Natl Acad Sci U S A (2000) 97:3579-84. doi:10.1073/pnas.97.7.3579

123. Reyna-Neyra A, Camacho-Arroyo I, Ferrera P, Arias C. Estradiol and progesterone modify microtubule associated protein 2 content in the rat hippocampus. Brain Res Bull (2002) 58:607-12. doi:10.1016/S0361-9230(02)00829-8

124. Reyna-Neyra A, Arias C, Ferrera P, Morimoto S, Camacho-Arroyo I. Changes in the content and distribution of microtubule associated protein 2 in the hippocampus of the rat during the estrous cycle. J Neurobiol (2004) 60:473-80. doi:10.1002/neu.20042

125. Ferreira A, Caceres A. Estrogen-enhanced neurite growth: evidence for a selective induction of tau and stable microtubules. J Neurosci (1991) 11:392-400.

126. Lorenzo A, Díaz H, Carrer H, Cáceres A. Amygdala neurons in vitro: neurite growth and effects of estradiol. J Neurosci Res (1992) 33:418-35. doi:10.1002/ jnr. 490330308

127. Diaz H, Lorenzo A, Carrer HF, Caceres A. Time lapse study of neurite growth in hypothalamic dissociated neurons in culture: sex differences and estrogen effects. J Neurosci Res (1992) 33:266-81. doi:10.1002/jnr.490330210

128. Camacho-Arroyo I, Gonzalez-Arenas A, Espinosa-Raya J, Pina-Medina AG, Picazo O. Short- and long-term treatment with estradiol or progesterone modifies the expression of GFAP, MAP2 and Tau in prefrontal cortex and hippocampus. Life Sci (2011) 89:123-8. doi:10.1016/j.lfs.2011.05.008

129. Guerra-Araiza C, Amorim MA, Camacho-Arroyo I, Garcia-Segura LM. Effects of progesterone and its reduced metabolites, dihydroprogesterone and tetrahydroprogesterone, on the expression and phosphorylation of glycogen synthase kinase-3 and the microtubule-associated protein tau in the rat cerebellum. Dev Neurobiol (2007) 67:510-20. doi:10.1002/dneu.20383

130. González SL, López-Costa JJ, Labombarda F, Deniselle MCG, Guennoun $\mathrm{R}$, Schumacher M, et al. Progesterone effects on neuronal ultrastructure and expression of microtubule-associated protein 2 (MAP2) in bats with acute spinal cord injury. Cell Mol Neurobiol (2009) 29:27-39. doi:10.1007/ s10571-008-9291-0
131. Bridges RS. A quantitative analysis of the roles of dosage, sequence, and duration of estradiol and progesterone exposure in the regulation of maternal behavior in the rat. Endocrinology (1984) 114:930-40. doi:10.1210/ endo-114-3-930

132. González-Arenas A, Piña-Medina AG, González-Flores O, Galván-Rosas A, Gómora-Arrati P, Camacho-Arroyo I. Sex hormones and expression pattern of cytoskeletal proteins in the rat brain throughout pregnancy. J Steroid Biochem Mol Biol (2014) 139:154-8. doi:10.1016/j.jsbmb.2013.01.005

133. Bridges RS, Hammer RP Jr. Parity-associated alterations of medial preoptic opiate receptors in female rats. Brain Res (1992) 578:269-74. doi:10.1016/0006-8993(92)90257-A

134. Keyser-Marcus L, Stafisso-Sandoz G, Gerecke K, Jasnow A, Nightingale L, Lambert KG, et al. Alterations of medial preoptic area neurons following pregnancy and pregnancy-like steroidal treatment in the rat. Brain Res Bull (2001) 55:737-45. doi:10.1016/S0361-9230(01)00554-8

135. González-Arenas A, Piña-Medina AG, González-Flores O, Gómora-Arrati P, Carrillo-Martínez GE, Balandrán-Ruíz MA, et al. Expression pattern of tau in the rat brain during pregnancy and the beginning of lactation. Brain Res Bull (2012) 89:108-14. doi:10.1016/j.brainresbull.2012.07.011

136. Evans DB, Rank KB, Bhattacharya K, Thomsen DR, Gurney ME, Sharma SK. Tau phosphorylation at serine 396 and serine 404 by human recombinant tau protein kinase II inhibits tau's ability to promote microtubule assembly. J Biol Chem (2000) 275:24977-83. doi:10.1074/jbc.M000808200

137. Regan P, Piers T, Yi J-H, Kim D-H, Huh S, Park SJ, et al. Tau phosphorylation at serine 396 residue is required for hippocampal LTD. J Neurosci (2015) 35:4804-12. doi:10.1523/JNEUROSCI.2842-14.2015

138. Nicholls RE, Alarcon JM, Malleret G, Carroll RC, Grody M, Vronskaya S, et al. Transgenic mice lacking NMDAR-dependent LTD exhibit deficits in behavioral flexibility. Neuron (2008) 58:104-17. doi:10.1016/j.neuron.2008.01.039

139. Kang H-S, Lee C-K, Kim J-R, Yu S-J, Kang S-G, Moon D-H, et al. Gene expression analysis of the pro-oestrous-stage rat uterus reveals neuroligin 2 as a novel steroid-regulated gene. Reprod Fertil Dev (2004) 16:763-72. doi:10.1071/RD04040

140. Akama KT, McEwen BS. Estrogen stimulates postsynaptic density-95 rapid protein synthesis via the Akt/protein kinase B pathway. J Neurosci (2003) 23:2333-9.

141. Rasooli-Nejad S, Palygin O, Lalo U, Pankratov Y. Cannabinoid receptors contribute to astroglial $\mathrm{Ca}(2)(+)$-signalling and control of synaptic plasticity in the neocortex. Philos Trans R Soc Lond B Biol Sci (2014) 369:20140077. doi:10.1098/rstb.2014.0077

142. Elobeid A, Bongcam-Rudloff E, Westermark B, Nister M. Effects of inducible glial fibrillary acidic protein on glioma cell motility and proliferation. J Neurosci Res (2000) 60:245-56. doi:10.1002/ (SICI) 1097-4547(20000415)60:2<245::AID-JNR14>3.0.CO;2-1

143. Toda M, Miura M, Asou H, Sugiyama I, Kawase T, Uyemura K. Suppression of glial tumor growth by expression of glial fibrillary acidic protein. Neurochem Res (1999) 24:339-43. doi:10.1023/A:1022538810581

144. Potokar M, Kreft M, Li L, Daniel Andersson J, Pangrsic T, Chowdhury HH, et al. Cytoskeleton and vesicle mobility in astrocytes. Traffic (2007) 8:12-20. doi:10.1111/j.1600-0854.2006.00509.x

145. Liedtke W, Edelmann W, Bieri PL, Chiu FC, Cowan NJ, Kucherlapati R, et al. GFAP is necessary for the integrity of CNS white matter architecture and long-term maintenance of myelination. Neuron (1996) 17:607-15. doi:10.1016/S0896-6273(00)80194-4

146. Eddleston M, Mucke L. Molecular profile of reactive astrocytes - implications for their role in neurologic disease. Neuroscience (1993) 54:15-36. doi:10.1016/0306-4522(93)90380-X

147. Otani N, Nawashiro H, Fukui S, Ooigawa H, Ohsumi A, Toyooka T, et al. Enhanced hippocampal neurodegeneration after traumatic or kainate excitotoxicity in GFAP-null mice. J Clin Neurosci (2006) 13:934-8. doi:10.1016/j. jocn.2005.10.018

148. Day JR, Laping NJ, Lampert-Etchells M, Brown SA, O’Callaghan JP, McNeill $\mathrm{TH}$, et al. Gonadal steroids regulate the expression of glial fibrillary acidic protein in the adult male rat hippocampus. Neuroscience (1993) 55:435-43. doi:10.1016/0306-4522(93)90512-E

149. Conejo NM, Gonzalez-Pardo H, Cimadevilla JM, Arguelles JA, Diaz F, Vallejo-Seco G, et al. Influence of gonadal steroids on the glial fibrillary acidic protein-immunoreactive astrocyte population in young rat hippocampus. $J$ Neurosci Res (2005) 79:488-94. doi:10.1002/jnr.20372 
150. Del Cerro S, Garcia-Estrada J, Garcia-Segura LM. Neuroactive steroids regulate astroglia morphology in hippocampal cultures from adult rats. Glia (1995) 14:65-71. doi:10.1002/glia.440140109

151. Storer PD, Jones KJ. Glial fibrillary acidic protein expression in the hamster red nucleus: effects of axotomy and testosterone treatment. Exp Neurol (2003) 184:939-46. doi:10.1016/S0014-4886(03)00339-X

152. Nilsson M, Pekny M. Enriched environment and astrocytes in central nervous system regeneration. J Rehabil Med (2007) 39:345-52. doi:10.2340/16501977-0084

153. Arias C, Zepeda A, Hernández-Ortega K, Leal-Galicia P, Lojero C, CamachoArroyo I. Sex and estrous cycle-dependent differences in glial fibrillary acidic protein immunoreactivity in the adult rat hippocampus. Horm Behav (2009) 55:257-63. doi:10.1016/j.yhbeh.2008.10.016

154. Gómora-Arrati P, González-Arenas A, Balandrán-Ruiz MA, MendozaMagaña ML, González-Flores O, Camacho-Arroyo I. Changes in the content of GFAP in the rat brain during pregnancy and the beginning of lactation. Neurosci Lett (2010) 484:197-200. doi:10.1016/j.neulet.2010.08.052

155. Garcia-Segura LM, McCarthy MM. Minireview: role of glia in neuroendocrine function. Endocrinology (2004) 145:1082-6. doi:10.1210/en.2003-1383

156. Mong JA, Blutstein T. Estradiol modulation of astrocytic form and function: implications for hormonal control of synaptic communication. Neuroscience (2006) 138:967-75. doi:10.1016/j.neuroscience.2005.10.017

157. Rozovsky I, Wei M, Stone DJ, Zanjani H, Anderson CP, Morgan TE, et al. Estradiol (E2) enhances neurite outgrowth by repressing glial fibrillary acidic protein expression and reorganizing laminin. Endocrinology (2002) 143:636-46. doi:10.1210/endo.143.2.8615

158. Cervantes M, González-Vidal MD, Ruelas R, Escobar A, Moralí G. Neuroprotective effects of progesterone on damage elicited by acute global cerebral ischemia in neurons of the caudate nucleus. Arch Med Res (2002) 33:6-14. doi:10.1016/S0188-4409(01)00347-2

159. Hoffman GE, Merchenthaler I, Zup SL. Neuroprotection by ovarian hormones in animal models of neurological disease. Endocrine (2006) 29(2):217. doi:10.1385/ENDO:29:2:217

160. Nilsen J, Brinton RD. Impact of progestins on estrogen-induced neuroprotection: synergy by progesterone and 19-norprogesterone and antagonism by medroxyprogesterone acetate. Endocrinology (2002) 143:205-12. doi:10.1210/en.143.1.205

161. Singh M, Su C. Progesterone-induced neuroprotection: factors that may predict therapeutic efficacy. Brain Res (2013) 1514:98-106. doi:10.1016/j. brainres.2013.01.027

162. Opendak M, Gould E. Adult neurogenesis: a substrate for experience-dependent change. Trends Cogn Sci (2015) 19:151-61. doi:10.1016/j. tics.2015.01.001

163. Duarte-Guterman P, Yagi S, Chow C, Galea LAM. Hippocampal learning, memory, and neurogenesis: effects of sex and estrogens across the lifespan in adults. Horm Behav (2015) 74:37-52. doi:10.1016/j.yhbeh.2015.05.024

164. Chan M, Chow C, Hamson DK, Lieblich SE, Galea LAM. Effects of chronic oestradiol, progesterone and medroxyprogesterone acetate on hippocampal neurogenesis and adrenal mass in adult female rats. J Neuroendocrinol (2014) 26:386-99. doi:10.1111/jne.12159

165. Zheng J, Zhang P, Li X, Lei S, Li W, He X, et al. Post-stroke estradiol treatment enhances neurogenesis in the subventricular zone of rats after permanent focal cerebral ischemia. Neuroscience (2013) 231:82-90. doi:10.1016/j. neuroscience.2012.11.042

166. Li J, Siegel M, Yuan M, Zeng Z, Finnucan L, Persky R, et al. Estrogen enhances neurogenesis and behavioral recovery after stroke. J Cereb Blood Flow Metab (2011) 31:413-25. doi:10.1038/jcbfm.2010.181

167. Suzuki S, Gerhold LM, Böttner M, Rau SW, Dela Cruz C, Yang E, et al. Estradiol enhances neurogenesis following ischemic stroke through estrogen receptors $\alpha$ and $\beta$. J Comp Neurol (2007) 500:1064-75. doi:10.1002/cne.21240

168. Li Z, Wang B, Kan Z, Zhang B, Yang Z, Chen J, et al. Progesterone increases circulating endothelial progenitor cells and induces neural regeneration after traumatic brain injury in aged rats. J Neurotrauma (2012) 29:343-53. doi:10.1089/neu.2011.1807
169. Stiess M, Bradke F. Neuronal polarization: the cytoskeleton leads the way. Dev Neurobiol (2011) 71:430-44. doi:10.1002/dneu.20849

170. Sudo S, Wen TC, Desaki J, Matsuda S, Tanaka J, Arai T, et al. $\beta$-Estradiol protects hippocampal CA1 neurons against transient forebrain ischemia in gerbil. Neurosci Res (1997) 29:345-54. doi:10.1016/S0168-0102(97)00106-5

171. Espinosa-García C, Aguilar-Hernández A, Cervantes M, Moralí G. Effects of progesterone on neurite growth inhibitors in the hippocampus following global cerebral ischemia. Brain Res (2014) 1545:23-34. doi:10.1016/j. brainres.2013.11.030

172. Shi J, Panickar KS, Yang SH, Rabbani O, Day AL, Simpkins JW. Estrogen attenuates over-expression of beta-amyloid precursor protein messager RNA in an animal model of focal ischemia. Brain Res (1998) 810:87-92. doi:10.1016/S0006-8993(98)00888-9

173. Simpkins JW, Singh M. More than a decade of estrogen neuroprotection. Alzheimers Dement (2008) 4:S131-6. doi:10.1016/j.jalz.2007.10.009

174. Petanceska SS, Nagy V, Frail D, Gandy S. Ovariectomy and 17beta-estradiol modulate the levels of Alzheimer's amyloid beta peptides in brain. Exp Gerontol (2000) 35:1317-25. doi:10.1016/S0531-5565(00)00157-1

175. Hampl R, Bicíková M. Neuroimmunomodulatory steroids in Alzheimer dementia. J Steroid Biochem Mol Biol (2010) 119:97-104. doi:10.1016/j. jsbmb.2010.02.007

176. Alvarez-de-la-Rosa M, Silva I, Nilsen J, Pérez MM, García-Segura LM, Avila J, et al. Estradiol prevents neural tau hyperphosphorylation characteristic of Alzheimer's disease. Ann N Y Acad Sci (2005) 1052:210-24. doi:10.1196/ annals. 1347.016

177. Paganini-Hill A, Henderson VW. Estrogen replacement therapy and risk of Alzheimer disease. Arch Intern Med (1996) 156:2213-7. doi:10.1001/ archinte.1996.00440180075009

178. Wang Q, Santizo R, Baughman VL, Pelligrino DA, Iadecola C. Estrogen provides neuroprotection in transient forebrain ischemia through perfusion-independent mechanisms in rats. Stroke (1999) 30:630-7. doi:10.1161/01. STR.30.3.630

179. Regan RF, Guo Y. Estrogens attenuate neuronal injury due to hemoglobin, chemical hypoxia, and excitatory amino acids in murine cortical cultures. Brain Res (1997) 764:133-40. doi:10.1016/S0006-8993(97)00437-X

180. Bonnefont AB, Muñoz FJ, Inestrosa NC. Estrogen protects neuronal cells from the cytotoxicity induced by acetylcholinesterase-amyloid complexes. FEBS Lett (1998) 441:220-4. doi:10.1016/S0014-5793(98)01552-X

181. Guennoun R, Benmessahel Y, Delespierre B, Gouézou M, Rajkowski KM, Baulieu EE, et al. Progesterone stimulates Krox-20 gene expression in Schwann cells. Mol Brain Res (2001) 90:75-82. doi:10.1016/S0169-328X(01)00094-8

182. Sereda MW, Meyer zu Hörste G, Suter U, Uzma N, Nave K-A. Therapeutic administration of progesterone antagonist in a model of Charcot-MarieTooth disease (CMT-1A). Nat Med (2003) 9:1533-7. doi:10.1038/nm957

183. Jung-Testas I, Schumacher M, Robel P, Baulieu EE. Actions of steroid hormones- and growth factors on glial cells of the central and peripheral nervous system. J Steroid Biochem Mol Biol (1994) 48:145-54. doi:10.1016/0960-0760(94)90261-5

184. Baulieu E, Schumacher M. Progesterone as a neuroactive neurosteroid, with special reference to the effect of progesterone on myelination. Steroids (2000) 65:605-12. doi:10.1016/S0039-128X(00)00173-2

Conflict of Interest Statement: The authors declare that the manuscript was prepared in the absence of any commercial or financial relationships that could be construed as potential conflicts of interest.

Copyright (c) 2015 Hansberg-Pastor, González-Arenas, Piña-Medina and CamachoArroyo. This is an open-access article distributed under the terms of the Creative Commons Attribution License (CC BY). The use, distribution or reproduction in other forums is permitted, provided the original author(s) or licensor are credited and that the original publication in this journal is cited, in accordance with accepted academic practice. No use, distribution or reproduction is permitted which does not comply with these terms. 